\title{
FROM TEXTUALITY TO UNIVERSALITY The Evolution of Hirābab Crimes in Islamic Jurisprudence
}

\author{
Moh Khasan \\ State Islamic University of Walisongo, Semarang \\ email:moh_khasan@walisongo.ac.id
}

\section{Abstract}

The issue of the escalation of crime, which is increasingly varied and is getting heavier, is becoming a global concern. The development and progress of the world seems to have contributed to changes in the type and quality of crime, not only in the form and method, but also in the damage it causes. Crime trends increasingly point to collective crimes, systematic crimes, and crimes with extensive and massive excess damage. This article intends to criticize the systematic change (evolution) that has occurred in the concept of biräbah crime in Islamic law from a classical to contemporary perspective. The qualitative analysis of this article is focused on three fundamental issues, namely; hiräbah interpretation, hiräbah liability, and hiräbah punishment. The author reveals in the conclusion that; first, based on its elements and characteristics, the definition of biräbah can be expanded to include new types of crimes such as; terrorism, rape, and drug trafficking and smuggling. Second, it is necessary to reconstruct the biräbah responsibility theory into a formulation that considers the principle of legal certainty and the principle of equality before the law. The reconstruction model, among others, is the affirmation that allpeople who involve themselves in the crime are perpetrators of hiräbah (with an ishtiräk approach). Likewise, reconstruction efforts are needed to enforce equality of accountability between male and female actors. Third, as a serious crime, hiräbah deserves a severe punishment and has a strong deterrent effect, as offered by Islamic law. However, the opportunity to give dispensation to the punishment will always 
be open if the perpetrator can prove his seriousness in repenting. [Eskalasi kriminalitas yang semakin beragam dan berat telah menjadi perbatian global saat ini. Pembangunan dan kemajuan dunia berkontribusi pada perubahan pola dan tingkat kriminalitas, tidak banya bentuk dan cara, tetapi juga akibat yang ditimbulkan. Trend kriminalitas berkembang mulai dari yang berkelompok, sistematis, bingga menyebabkan kerusakan yang masif dan lama. Tulisan ini mengkritisi perubahan sistematis pada konsep jarimah hiräbah dalam hukum Islam dari pendekatan klasike bingga kontemporer. Analisis kualitatif dalam tulisan ini fokus pada tiga hal mendasar yaitu pemaknaan, pertanggungjawaban dan bukuman hiräbah. Kesimpulan pertama tulisan ini adalah bahwa definisi hiräbah berdasarkan unsur dan karakteristikny a dapat diperluas mencakup terorisme, pemerkosaan, perdagangan dan penyelundupan obat-obat terlarang. Kedua, perlu rekonstruksi teori pertanggungjawaban ḩiräbah menuju formulasi yang mempertimbangkan kepastian bukum dan kesetaraan bak dimuka bukum. Ketiga, sebagai kejahatan serius, hiräbah pantas mendapat hukuman berat dan mempunyai efek, pencegahan yang kuat seperti halnya dalam bukum Islam. Meski demikian, ada peluang dispensasi bukuman jika pelaku dapat menunjukkan kesungguban untuk bertobat.]

Keywords: Hiräbah, Human Rights, Islamic Criminal Law

\section{A. Introduction}

This article focuses on the new perspective of hiräbah as classical and contemporary issue. The assumption lies on the existence of a systematic change in the concept of hiräbab in Islamic jurisprudence. This article is also based on the argument that the issue of the escalation of crime, which is increasingly varied and is getting heavier, is becoming a global concern. The development and progress of the world seems to have contributed to changes in the type and quality of crime, not only in the form and method, but also in the damage caused by the crime. Crime trends increasingly point to collective crimes, systematic crimes, and crimes with extensive and massive excess damage. Therefore, fresh thinking is needed which can be a legal solution for the rise of new and modern types of crimes in accordance with the new and better world order. 
The first aim of this article is to critically analyse about the interpretation of biräbah crime in Islamic jurisprudence. The criminalization concept of hiräbah is merely unclear in describing violations of the law. That is why this sparked debate among the jurists. For example, in the case of defining biräbah, Islamic criminal law interprets biräbah as type of crime which is related to taking property of others by force and openly. There is a significant difference in the interpretation of biräbah between classical Muslim's scholar and contemporary Muslim's scholars. Classical Muslim's scholars define biräbah textually, and even tend to be conservative. This interpretation results in the definition of biräbah being unclear and absurd. Hiräbah's limits still overlap with other types of criminal acts, such as theft, robbery and rebellion.

Meanwhile, in the context of the trend of evil in modern times, this hiräbah crimes also becomes interesting to discuss because of the increasing number of types of evil that tend to be close to the character with it. These characters, such as collectivity, systematic, social and political potential conflicts, and the effects of the damage they cause are very close to the biräbah crimes. The perpetrators of the theft no longer commit crimes by secretly and alone. Likewise, other perpetrators of this crime, dominated by crimes committed collectively, organized and systematic. Therefore, some researchers include several types of serious crimes as hiräbah because of their close nature and character to it. For example, security disturbances, ${ }^{1}$ robery, ${ }^{2}$ terrorism, ${ }^{3}$ smuggling and trafficking drugs, ${ }^{4}$ and rape. ${ }^{5}$

This article is also aim to critically analyse the debate among jurists about the hiräbah crimes in other concepts, such as who is the perpetrator

1 See Ahmad Hanafi, Asas-Asas Hukum Pidana Islam (Jakarta: Bulan Bintang, 2005), pp. 273-7.

${ }^{2}$ See Abd al-Qādir 'Audah, al-Tashrì' al-Jinà' al-Islāmì (Beirut: Dār al-Kitab al'Arabi); M. Cherif Bassiouni (ed.), The Islamic Criminal Justice System (London; New York: Oceana Publications, 1982); Nik Rahim Nik Wajis, The Crime of Hirābah in Islamic Law (Glasgow: Glasgow Caledonian University, 1996).

3 Mohammad Hashim Kamal, "Terrorism, Banditry and Hirabah: Advancing New Shariah Perspectives", Islam and Civilisational Renewal., vol. 8, no. 1 (2017), pp. 11-34; Wajis, The Crime of Hiräbah in Islamic Law.

4 Wajis, The Crime of Hiräbah in Islamic Law, pp. 197-200.

5 Ibid., pp. 169-70. 
of the biräbah, how is the liability of the biräbah, and the problem of applying the hiräbah punishment. This discussion and debate on the one hand certainly represent different arguments from jurists, but on the other hand contain interesting material when analyzed with a modern and universal perspective, like human rights. As stated by Rudolph Peters that, although Islamic criminal law protects a number of important fundamental rights, such as the rights to life and the integrity of the holy, the syari'a criminal law as applied today is in conflict with human rights standards in the following areas; a) the principle of nulla poena sine lege, i.e. that punishment may be awarded on the strength of law defining the offence and its punishment; b) the principle that all persons are equal before the law; c) the ban on cruel, degrading or inhuman punishment; d) freedom of religion and freedom of expression; e) the basic right of children not to be subjected to the death penalty, life imprisonment and cruel, degrading or inhuman punishment. ${ }^{6}$

Specifically, the report focuses on four principal issues in biräbah discourse: interpretation of hiräbah, liability of hiräbah, and punishment of hiräbah, -issues which can be regarded as the key elements of hiräbah discourse.

\section{B. Definition and Meaning of Hiräbab; Textual and Universal Perspective}

Criminal law in other legal systems tends to be organized according to the nature of crimes, but under classical Islamic law are categorized according to the nature and sources of punishments. Islamic criminal offenses are divided into three categories: (1) offenses and punishments fixed in the Qur'an or Sunna (budüd); (2) offenses against the person, including intentional injury and homicide, which are considered matters to be settled between the offender and victim, and for which remedies include retaliation (qișass) and financial compensation (diy $\bar{a} t$ ); and (3) Offenses not fixed in the Qur' an or Sunnah, for which punishments are discretionary $\left(t a^{\prime} z_{i} i r\right)$. In recent years, Islamic criminal law has been the subject of commentary and critique by scholars and activists within the

${ }^{6}$ Rudolph Peters, Crime and Punishment in Islamic Law: Theory and Practice from the Sixteenth to the Twenty-First Century (Cambridge: Cambridge University Press, 2005), pp. $174-5$. 
international human rights community.

Hiräbah is usually equated with qat'u al-tariq, a group of people who cause trouble, bloodshed, seizure of wealth, honor, order, and create chaos on earth. ${ }^{7}$ The Hanafi's scholars, al-Kasani (d.1191/587), defined biräbah (or qat'u al-tariq) as 'attacks upon pedestrians for the purpose of taking their property by force in such a way that people are rendered unable to pass freely through the streets. The attacker/s may be a group or a single person that possess[es] overwhelming power to obstruct the public passage, and maybe using weapons or weapon-substitutes such as sticks and stones. ${ }^{8}$ The Maliki school defined the agents of hirābah as "anyone who brandishes weapons in order [to] obstruct free passage in the streets rendering them unsafe to travel by killing people, taking their money, and spreading corruption in the land. The agent of biräbah/ mubärib may be a Muslim or a non-Muslim, free or slave, and it may be committed in city or countryside, by an individual or group-simply because the Qur'an has not specified the perpetrator in any such ways."'

Meanwhile, Shafi'i's school identifies the agents of biräbab in similar terms, but while stressing that the perpetrator must be a competent person (mukallaf) and either a Muslim, a dbimmi or an apostate who is bound by the injunctions of Islam and has overwhelming power to subjugate others and take their money and property in an area away from a main city. ${ }^{10}$ A slightly different definition is conveyed by Imam Malik, that biräbah is taking wealth with deception (tactics), whether using force or not. ${ }^{11}$ Hiräbab is also understood as an act of crime or destruction using weapons/tools carried out by humans openly anywhere, whether done

7 Sayyid Sābiq, Fiqh Sunnah, vol. 2 (Cairo: Dār Fath al-I'lām al-'Arabī, 1999), p. 393.

8 'Alauddin Al-Kasāni, Bada’' al-Sana'i fi Tartīb al-Sharā’i, vol. 7 (Beirut: Dār al-Kutub al-'Ilmiyyah, 1997).

9 Sābiq, Fiqh Sunnah, 2: 298; Ibn 'Abd Al-Barr, al-Käfi fì Fiqh al-Madinah al-Mālikè (Beirut: Dar al Kutub al-Ilmiyah, 1999), pp. 582-3.

10 Shamsuddīn Muḥammad bin Muhammad al-Khatīb al-Sharbīnī, Mughni alMuḅtāj ilā Márifat Ma'āni al-Alfā̌a al-Minhāj, vol. 4 (Cairo: Muṣtafā al-Bābī al-Halabi, 1933).

11 Ibid., p. 641. Imam Malik believes that assassinations carried out by ruse are more dangerous than open killings. This has implications for allowing apology in the type of murder openly. Therefore, this action falls into the category of qisas and murder by deception falls into the category of hiräbah. 
by one person or in a group without thinking about who the victims are accompanied by acts of violence. ${ }^{12}$ The Prophet even categorized the perpetrators of hiräbah as not including Muslims, based on the hadith: "man hamala alayna al-siläh fa laysa minna" (narrated by Bukhari and Muslim, from ibn Umar). ${ }^{13}$

According to Sayyid Sābiq, crime of hirābah can take several forms; First, someone comes out with the intention of taking property openly and intimidating, but does not taking the property and does not killing. ${ }^{14}$ If they only scare not to seize property and not commit murder, they will simply be jailed and $t a^{\prime}$ 'rir. ${ }^{15}$ Second, someone comes out with the intention of taking the property openly, so that he can take the property but not killing. ${ }^{16}$ If they only confiscate property of approximately one nișäb, such as theft and murder, then their hands and feet must be cross-cut. ${ }^{17}$ The right hand must be cut off because of the act of seizing property, such as the penalty stipulated in ordinary theft. The left leg was cut off because of an attack. ${ }^{18}$ Third, someone departs with the intention of taking property, but commits murder and does not taking property. ${ }^{19}$ If they commit murder without taking property, they must be put to death for following the provisions above. Why should they be sentenced to death, even though the guardian of the victim has forgiven him? Because, they try to integrate fear using methods that demand heavier penalties into their crimes. ${ }^{20}$ Fourth, someone intends to take the property, so that

12 Abdur Rahman I. Doi, Tindak Pidana dalam Syariat Islam (Jakarta: Rineka Cipta, 1992), p. 57.

13 Muhammad bin Ismail bin Ibrahim Al-Bukhari, Sabih al-Bukhari (Beirut: Dar al-Fikr, 1994), p. 1246.

14 Sābiq, Fiqh Sunnah, 2: 87.

15 Wahbah Al-Zuhailī, al-Figh al-Shäfíi al-Muyassar, vol. 3, ed. by Muhammad Afifi Abdul Hafiz (Beirut: Dar al-Fikr, 2008).

16 Sābiq, Fiqh Sunnah, 2: 87.

17 Sayyid Bakri bin Sayyid Muhammad Shața, I'ānah al-Ṭälibìn, vol. 4 (Surabaya: Haramain, 2007).

18 Ibid.

19 Sābiq, Fiqh Sunnah, 2: 87.

20 Taqī al-Dīn Abū Bakr ibn Muhammad Hiṣnī, Kifāyat al-akhyār fì ḥall Ghāyat al-ikhtiṣār, vol. 2 (Beirut: Dār al-Kutub al-'Ilmīyah, 2012). 
later managed to take the property and kill the owner, ${ }^{21}$ then they must be put to death and then crucified for three days so that these conditions are published and the deterrent effect is perfect. ${ }^{22}$

Among three terms that are commonly used to describe this type of crime, hiräbah (armed robbery), qat'u l-täriq (highway robbery), sariqah kubrä (grand theft), hiräbah is considered the most representative term because of its closeness to the text of the verse which is the proposition, yubăribu. Therefore, armed robbery becomes a very familiar meaning for the term hiräbah even by most jurists. Nevertheless, limiting the definition of biräbah crimes as armed robbery feels very simplistic and out of context. At least there are two important reasons; firstly, the indicator shown by Qur'an, 5: 33. The verse uses specific terms -but has a general meaning- to describe the hiräbah crimes, which is uniquely different from the term used in the other crime of budüd, like zina, qadzaf, sariqah, and syurb al-khamr. These terms are: yubäribüna Alläh wa rasūlahu, and yas'auna fi al-ardi fasädan. Both phrase of the criminalization of the hiräbah crimes indicate the existence of an unusual and not simple category of crime, so that at least a comprehensive understanding is needed to know the purpose of the two limits. Therefore it is necessary to have a broader meaning (extended definition) to the term biräabah.

The uniqueness of biräbah can be seen from both, the threat of punishment and the background of legislation (asbāb al-nuгūi). Unlike other budūd, hiräbab is threatened with four heavy and varied punishment, namely: killed, crucified, crossed with arms and legs, and exiled. Characteristics of punishment like this clearly show that this type of crime is different from ordinary budüd, which is usually only threatened with one type of punishment. Asbäb al-nuqüland the historical setting of Qur'an, 5: 33 also have crucial meaning for hiräbah. Scholars differ about the historical setting of the verse.

Abou el-Fadl notes that there are at least six opinions about the historical setting of the verse. Firstly, it relates to the people of the book who had an agreement with the Prophet, but they betrayed the agreement and caused damage on earth, so this verse came down. Secondly, the narratives related to the tribe of Hilal bin 'Uwaymir, which involved a

21 Sābiq, Fiqh Sunnah, 2: 87.

22 Al-Zuhailī, al-Figh al-Shäfi'i al-Muyassar, 3: 326. 
mutual agreement not to attack any groups that passed in front of the Hilal tribe to face the Prophet. But when a group from Banū Kinānah passed by to join the Prophet, the Hilal attacked, killed people, and stole their properties. Thirdly, that the verse was revealed in connection with a polytheist group that attacked Muslims, made mischief on earth, and then fled to non-Muslim territory before they were captured. Fourthly, with a brief elaboration, stating that the verse came down related to the Bani Israel. Fifthly, the verse is related to the Hurriyyah group (the forerunner to the Khawarij). Sixthly, a statement supported by many controversies, that a group of people from the Uraynah tribe embraced Islam and came to Medina in a state of illness. They complained to the Prophet that they were people from the desert so they could not live (adapt) well in Medina. The Prophet sent a camel to them so that, in accordance with their customs in the village, he could drink his milk and urine to restore his health. The Prophet also included with them a shepherd from the Nubian tribe named Yasar. The people of the Uraynah tribe lived in a place about 6 miles from Medina, named Liqähah, until they were well again. But it turns out that later they apostatized and tortured the shepherd, by chopping his limbs, putting thorns in his eyes, and crucifying him. They stole their camels and ran away. After capturing them, the Prophet cut off their arms and legs crossed, blinded their eyes, and crucified them and then left them to die in the desert. According to some accounts, after killing them, the Prophet also burned their bodies. ${ }^{23}$

Based on some of the thoughts above, it is reasonable if the researchers recommend expanding the understanding of hiräbah. Some latter scholars, like Abdullahi Ahmed an-Na'im, ${ }^{24}$ Khaled M. Abou el-

${ }^{23}$ Khaled Abou El Fadl, Rebellion and Violence in Islamic Law, First edition (Cambridge; New York: Cambridge University Press, 2001), pp. 49-50.

24 Abdullahi Ahmed al-Na'im (from Sudan) is Charles Howard Candler Professor of Law at Emory Law, associated professor in the Emory College of Arts and Sciences, and senior fellow of the Center for the Study of Law and Religion of Emory University. An internationally recognized scholar of Islam and human rights and human rights in cross-cultural perspectives, An-Na'im teaches courses in international law, comparative law, human rights, and Islamic law. His research interests include constitutionalism in Islamic and African countries, secularism, and Islam and politics. An-Na'im directed the following research projects which focus on advocacy strategies for reform through internal cultural transformation: Women and Land in Africa, Islamic Family Law, Fellowship Program in Islam and Human Rights, The Future of 
Fadl, ${ }^{25}$ and M. Hashim Kamali ${ }^{26}$ have valuable attention to this discourse. An-Na'im states that one of the striking weaknesses of classical criminal law is that there is too much legal uncertainty, such as the absence of a clear-cut definition of what is meant by mubäribün (rebel). Even some jurisprudents call it the qat'u tariq (robery) even though in fact the two

Sharia: Islam and the Secular State. An-Na'im's current research projects include a study of Muslims and the secular state, and of human rights from state-centric to peoplecentered. He continues to further develop his theory of Islam and the Secular State. Abdullahi Ahmed An-Na'im, Islam and the Secular State: Negotiating the Future of Shari a (Cambridge: Harvard University Press, 2008). Also published in Arabic and Indonesian. Translations of this manuscript in Bengali, Persian, Urdu, Bengali, Turkish and Russian, are available for download free of charge at sharia.law.emory.edu. See 'Abdullahi Ahmed An-Na'im, Emory University School of Law', Profile, http://law.emory.edu/faculty/ faculty-profiles/annaim-profile.html, accessed 2 Nov 2020; Abdullahi Ahmed AnNa'im, Future of Shari'a, https://scholarblogs.emory.edu/aannaim/future-of-sharia-2/, accessed 11 Feb 2020.

25 Dr. Khaled Abou El Fadl is one of the world's leading authorities on Islamic law and Islam, and a prominent scholar in the field of human rights. He is the Omar and Azmeralda Alfi Distinguished Professor in Islamic Law at the UCLA School of Law where he teaches International Human Rights, Islamic Jurisprudence, National Security Law, Law and Terrorism, Islam and Human Rights, Political Asylum and Political Crimes and Legal Systems. He is also the Chair of the Islamic Studies Interdepartmental Program at UCLA. He has lectured on and taught Islamic law throughout the United States and Europe in academic and non-academic environments for over twenty years. His work has been translated into numerous languages including Arabic, Persian, French, Norwegian, Dutch, Ethiopian, Russian, and Japanese, among others. See "Khaled Abou El Fadl”, Program in Islamic Law (30 Apr 2019), https://pil.law.harvard.edu/advisors/ khaled-abou-el-fadl/, accessed 11 Feb 2020.

26 Mohammad Hashim Kamali, Founding CEO of IAIS Malaysia, graduated from Kabul University, and then obtained his PhD in Islamic and Middle Eastern Law at the University of London in 1976. He served as Professor of Islamic Law and Jurisprudence at the International Islamic University Malaysia (1985-2004), then Dean of the International Institute of Islamic Thought and Civilization (ISTAC) from 2004-2006. He was Asst Professor at McGill University's Institute of Islamic Studies; Visiting Professor at Capital University, Ohio; and the Wissenschaftskolleg, Berlin. He was a member of the Constitution Review Commission of Afghanistan (2003), and a UN shariah expert on the constitutions of Iraq, the Maldives and Somalia (2004-2005). He has published over 200 academic articles and 35 books. See "Professor Kamali", International Institute of Advanced Islamic Studies (IAIS) Malaysia, https://iais.org. my/staff-sp-2037227643/professor-kamali, accessed 11 Feb 2020. 
are very different. ${ }^{27}$ This criminal offense always refers to Qur'an, 5: 33. The question is what is meant by rebels? Are they critical of the government? Are those who have deliberately attacked the government? Are those who have attacked the government with weapons? Or those who are indifferent to the government that they no longer like? And what is meant by the perpetrators of damage/corruption on earth? All of this has not been well defined by classical Islamic law, so various interpretations emerge. ${ }^{28}$

Abou el-Fadl said that: "some scholars state that the traditional definition of biräbah should be extended to include acts of terrorism. Theoretically, the language 'cause corruption on the earth' (yas'auna fi 'l-ard fasädan) could be applied to a wide range of activities including anything from writing heretical poetry to raping and pillaging". ${ }^{29} \mathrm{He}$ even added: "Significantly, the language of the verse lends itself to use in the political field, and could easily be applied to rebellion or sedition. ${ }^{30}$ The Qur'an repeatedly condemns those who cause corruption on the earth. And in one verse, it associates fitna with corruption on the earth". ${ }^{31}$

Meanwhile, according to Hashim Kamali, hiräbah in the Qur'an is envisaged as a composite crime, subsuming banditry, highway robbery, terrorism, theft, and murder. It is a hadd crime consisting usually, but not necessarily, of collective or group activity committed by more than one person on behalf of that group. ${ }^{32}$ The Qur'anic phrase 'waging war on

27 Abdullahi Ahmed An-Na'im, Toward an Islamic Reformation: Civil Liberties, Human Rights, and International Law (Syracuse: Syracuse University Press, 1990).

28 Muhyar Fanani, Membumikan Hukum Langit: Nasionalisasi Hukum Islam dan Islamisasi Hukum Nasional Pasca Reformasi, ed. by Ibnu Burdah (Yogyakarta: Tiara Wacana, 2008), p. 186.

29 Fadl, Rebellion and Violence in Islamic Law. Khaled explain, this is so in legal theory, but the Qur'an limits corruption on the earth to the destruction of property; such as crops or, perhaps, the economic system, and the destruction of lives (iblak al-hars wa al-nash). See Qur'an 2: 205. The Qur'anic concept of corruption appears to be specific and limited although in Muslim practice it has been used rather expansively.

30 Abdullah Yusuf 'Ali, The Meaning of the Holy Qur'an (Beltsville, MD: Amana Publications, 1995); Khaled Abou El-Fadl, Rebellion and Violence in Islamic Law (Cambridge: Cambridge University Press, 2001).

31 Fadl, Rebellion and Violence in Islamic Law, p. 48.

32 Kamal, "Terrorism, Banditry and Hirabah: Advancing New Shariah Perspectives”, p. 12. 
God and His Messenger' placed jurists in a quandary as to its precise import and implications. A generic expression, it was evidently not meant literally. Since it is immediately followed by 'making mischief in the land-fasäd fil-ard', the two phrases have been read together in order to provide a clearer understanding of the verse. Yet this latter phrase, too, is less than specific, for 'fasäd fil-ard' can also include a variety of criminal activities and transgressions. Indeed, it has even been suggested that the latter phrase is wider than the former, in that spreading 'corruption in the earth' can include criminal activities that may not qualify as hiräbah as such. Hence, the relationship between the two phrases is seen as one of the particular (khass) to the general ('amm), in which case biräbah is seen as only one of the many manifestations of 'fasäd fi'l-ard'. ${ }^{33}$

Kamali seems agreed with al-Shawkani's thought (d.1835/1250) that the manifest meaning of 'fasäd fi'l-ard' is broad enough to subsume not only highway robbery, but also propagation of false deities (shirk), destruction of people's lives, looting their properties and attacking their dignity, as well as the destruction of trees, waterways and livestock, aggressive dictatorship and so forth. Some commentators have also included recidivist thieves and burglars, notorious rapists and homosexuals under hiräbah, as those who's evil and mischief-making cannot be stopped other than by execution. ${ }^{34}$

When Kamali explain about hiräbah and terrorism, he said that concerning terrorism, it has proven difficult to find a comprehensive definition; as many years of fruitless debate in the United Nations shows, it cannot be defined to the satisfaction of everyone. The one factor that underlines all terrorism, however, also underlies hiräbah: the desire to cause fear, terror, and insecurity in society through the indiscriminate use of violence, often for political ends. This characterisation of both terrorism and hiräbah covers acts of terror perpetrated by individuals, groups and even states (as exercised by Israel against the Palestinian people). ${ }^{35}$ In line with them, Sherman Jackson also carried out a rigorous analysis with the biräbah's perspective to terrorism crimes that occurred in the United

33 Ibid., p. 13.

34 Kamal, "Terrorism, Banditry and Hirabah: Advancing New Shariah Perspectives".

35 Ibid., p. 12. 
States. ${ }^{36}$ Expression, Frank E. Vogel states that tragedy of September 11th 2001 in the United States, if it is processed by the Islamic justice system, then the perpetrators will certainly be found guilty because they have been accused of committing hiräbah. ${ }^{37}$

Initiatives to expand the meaning of hiräbah have also been carried out by several Islamic countries through their constitution. Iran's Criminal Law (Islamic Penal Code of Iran) is one of them. In the stipulations concerning crime of hiräbah in article 183, it is stated that: "Any person who resorts to weapons to cause terror and fear or to breach public security and freedom shall be considered as a mohareb and corrupt on earth (mofsed fel-ary)" ${ }^{38}$ Likewise in article 185, it is stated: "If an armed robber or a highway robber, by resorting to weapons, disturbs public security or the security of roads, and causes fear and terror, shall be considered as a mohareb. ${ }^{.39}$

Meanwhile, in Saudi Arabia, in the case of biräbah, during the last two decades it seems that there has been a tendency for the King to withdraw from giving siyasa sentences and to leave the trial of serious crimes to the judiciary. This was heralded by a fatwa on the exact meaning of the crime of banditry (biräbah). In Fatwa No. 85 of the Board of Senior 'Ulama' (Hay'at al-Kibār al'Ulamā), issued on 9 September 1981, the law of biräbah was authoritatively expounded. The fatwa was motivated by reports of an increase in violent crimes in cities, in cases of abduction for sexual purposes and in drugs-related offences. The fatwa consists of two parts. The first one extends hadd offence of banditry by adopting the Malikite definition. The muftis rule that henceforth qädis may award the fixed punishments for banditry in case of armed attacks in cities and that abduction for sexual motives must be put on a par with the taking of property. Further, the fatwa a stipulates that the punishment imposed

36 See Sherman A. Jackson, "Domestic Terrorism in the Islamic Legal Tradition", The Muslim World, vol. 91, nos. 3-4 (2001), pp. 293-310.

37 Frank E. Vogel, “The Trial of Terrorists under Classical Islamic Law”, Harvard International Law Journal, vol. 43 (2002), p. 53.

38 Legal Affairs Commission of the Islamic Consultative Assembly, Islamic Penal Code of the Islamic Republic of Iran: Book One \& Book. Two (New Haven: Iran Human Rights Documentation Center, 1991), p. 28.

39 Legal Affairs Commission of the Islamic Consultative Assembly, Islamic Penal Code of the Islamic Republic of Iran. 
for banditry is no longer related to the existence of specific aggravating circumstances in addition to the 'hold up' and that judges, therefore, are free to choose any of the punishments mentioned in Qur'an, 5: 33-34 (banishment, cross-amputation, death or death with crucifixion). The second part of the fatwa deals with the trafficking and smuggling of drugs. Its sets forth that these crimes fall under the notion of 'spreading corruption on earth' (Qur'an, 5: 3-4) and provides that the first offence shall entail a severe discretionary punishment (imprisonment, flogging, fine) and that for a second offence that court may impose any penalty, including death. This applies also to drug users who are convicted for the second time. ${ }^{40}$

Hadd sentences for banditry can be inflicted by the courts for drug-related offences and in cases of bulgary and robbery committed in cities. The following case shows the extent to which the definition of banditry (biräbah) has now been stretched:

Three men, two of whom were dressed in women's clothes, including the face veil that is obligatory in Saudi Arabia, had gained access to a home, where, at that moment, only the lady of the house was present. They had phoned her earlier and told her that they had to deliver documents for her husband. Once inside, they had threatened the women with a knife, taken her jewellery and forced her to undress. Then they had taken pictures of her in the nude with polaroid camera. After they had left, they had contacted her by telephone and demanded money in exchange for the picture. Shortly thereafter they were caught and confessed to their crime. The men were then sentenced to death penalty for banditry. ${ }^{41}$

Meanwhile, Makhrus Munajat stated that given the crime in the modern age was very well organized, then the classical cleric's requirements regarding the provisions of the crime of biräbah need to

40 Issam Saliba, "Saudi Arabia: Twin Brothers Charged with Islamic Crime of Hiraba", Global Legal Monitor (2018), //www.loc.gov/law/foreign-news/article/ saudi-arabia-twin-brothers-charged-with-islamic-crime-of-hiraba/, accessed 12 Feb 2020; Peters, Crime and Punishment in Islamic Law: Theory and Practice from the Sixteenth to the Twenty-First Century.

41 Muhammad ibn 'Abd Allāh 'Umayrī, Musqitāt Hadd al-Hirābah wa Tatbīqātuhā fì al-Mamlake al-'A rabiyya al-Sa'ūdiyya (Riyadh: Akādīmiyāt Nayif al-'Arabiyya lil al-'Ulūm al-Aminyya, 1999), pp. 201-5. 
be revised, especially the requirements relating to the place and target. Hiräbah is not only happening in a place far from the crowd, because there are indications when it is done in a place far from the crowd it is impossible for the victim to get help. Crimes can now occur in crowded places such as banks, supermarkets with automatic weapons that perpetrators are free to carry out their actions and others are afraid to provide help. Targets are not only limited to property and lives, but security disturbances, such as sabotage, power outages, destruction of roads, drinking water channels, bombings, rape, and other forms of crime that have cause casualties, even lives, property and honor. ${ }^{42}$

\section{New Formulation of Hiräbab Crimes ${ }^{43}$}

\section{Terrorism as Hiräbab Crimes}

Some scholars state that the traditional definition of hiräbah should be extended to include acts of terrorism. ${ }^{44}$ The relationship and legal differences between brigandage and rebellion is explored in

42 Makhrus Munajat, Dekonstruksi Hukum Pidana Islam (Yogyakarta: Logung Pustaka, 2004), p. 120.

43 Why should hiräbah? There are at least two reasons. First, Conceptually, the categorization as birābah reflects: 1) the heavy jarimah because it belongs to the hudūd category, while ta'zir is a common jarimah; 2) the high level of damage contained by the jarimah. jarimah budüd has the character as jarimab which is dominated by Allah's right. Allah's right is a representation of the universal benefit (maslahat 'ammab). Second, the perspective of the principle of legality, namely the exception of the principle of retroactivity (the principle of rajiyyah) in Islamic criminal law. This principle applies against to the crime which is considered very dangerous (extra ordinary crime). The three jarimah which are categorized as very dangerous are qadzaf, hiräbah, and giihar. This categorization is also to some extent a maximum law enforcement effort, which is not possible if these veru dangerous jarimah, such as terrorism, drug trafficking \& trafficking, genocide, rape \& serious sexual violations, "only" categorized as jarimah ta'żir. See Muhammad Abū Zahrah, al-Jarimah wa al-'Uqübah fì al-Fiqh al-Islämì (Cairo: Dār al-Fikr al-'Arabī, 2013); Muḥammad Iqbal Șiddiqi, The Penal Law of Islam (New Delhi: International Islamic Publishers, 1994); Topo Santoso, Menggagas Hukum Pidana Islam: Penerapan dalam Syari'at Islam dalam Konteks Modernitas (Bandung: Asy-Syaamil Press \& Grafika, 2000); 'Audah, al-Tashrì' al-Jinā'̀ al-Islämī; Bassiouni (ed.), The Islamic Criminal Justice System.

44 Hikmahanto Juwana, Catatan Singkat RUU Anti Terorisme (Jakarta, 2002); Indriyanto Seno Adji, "Bali, Terorisme, dan Hak Asasi Manusia”, Kompas (29 Oct 2002). 
Abou el-Fadl. He states: "theoretically, the language 'cause corruption on the earth' (yas'auna fi al-ardi fasädan) could be applied to a wide range of activities including anything from writing heretical poetry to raping and pillaging." He also interpreted biräbah by relating it to the political field. He states that: "significantly, the language of the verse lends itself to use in the political field, and could easily be applied to rebellion or sedition." According to him, The Qur'an repeatedly condemns those who cause corruption on the earth. And in one verse, it associates fitna with corruption on the earth. ${ }^{45}$

In line with el-Fadl, Taqiyyuddin also categorizes terrorism as al-baghy, because in reality, the practice of terrorism also threatens the security and integrity of the country. Etimologically, al-baghy means wrongdoing or persecution, while terminologically, al-baghyu means people who oppose a just government and do not want to carry out what is their duty. ${ }^{46}$

The September 11th, 2001 tragedy has at least inspired the emergence of two important research. Starting from the assumption that there is a strong connection between Islam and the September 11th tragedy, Sherman Jackson and Frank E. Vogel, tried to study deeply the Islamic concept of crime. Finally, Jackson demonstrates that "the classical Islamic law of biräbah corresponds in its most salient features to the law of terrorism in the United Stated. This article presents a clear, thorough analysis of the law of biräbah"47 As for Vogel argues that: "if the perpetrators of the attack of September 11th 2001, were tried under classical Islamic law, they would be probably be found guilty of biraba". ${ }^{48}$

Terrorism in Arabic is known as irbäb, which means to frighten (cause fear). Irhăbi (terrorist) means a person who makes others feel scared, someone who scares others. ${ }^{49}$ Initially, the term terrorism was categorized as a crime against the state. One of them is the definition according to the 1937's UN Convention, that terrorism is any form

45 Fadl, Rebellion and Violence in Islamic Law, p. 48.

46 Hiṣnī, Kifāyat al-akbyār fi hall Ghāyat al-ikhtișār.

47 Jackson, "Domestic Terrorism in the Islamic Legal Tradition”, pp. 293-310.

48 Vogel, "The Trial of Terrorists under Classical Islamic Law".

49 Abduh Zulfidar Akaha (ed.), Terorisme \& Konspirasi Anti Islam (Jakarta: Pustaka al-Kautsar, 2002), p. 28. 
of crime committed directly against the state with the intention of creating terror against certain people, or groups of people or the wider community. ${ }^{50}$ However, it is feared that this understanding will lead to multiple interpretations that lead to the interests of the state where the authorities can expand the definition of terrorism according to their own interests. Therefore, in the next development, the definition of terrorism has shifted towards a more democratic understanding. Terrorism is then formulated as crimes against humanity which can be international, regional, and national in nature, especially when directed at the souls of innocent people (public by innocent). The definition of terrorism like that can be found in the European Convention on the Suppression of Terrorism (ECST) $1977 .{ }^{51}$

Terrorism can be categorized as crime of hiräbah, due to consideration of its constituent elements. Hashim Kamali implies that there are factors that underlines terrorism as hiräbab; like the desire to cause fear, terror, and insecurity in society through the indiscriminate use of violence, often for political ends. ${ }^{52}$ In line with Kamali, Nurul Irfan identified that hiräbah contains elements of robbery, torrents, amusement, hijacking, as well as other terms. Hiräbab is an act of violence committed by a person or group of people to others to control the property of others by frightening and sometimes accompanied by murder. In this case the perpetrators scare the victim with threats, criticism, and violence. Thus for the present context, assembling bombs and detonating them includes biräbah. ${ }^{53}$ Islam, represented by Ijtima' of The Indonesian Council of Ulama' (MUI) in Jakarta on December 14-16 2003 included terrorism as jarimah hiräbah, based on Qur'an 5: 33. The characteristics of terrorism according to the MUI fatwa are: 1 ) destructive (ifsād) and anarchic (fauda $)$ in nature; 2) the aim is to create fear, insecurity and/or destroy other groups; 3) done without rules and unlimited goals. ${ }^{54}$

50 Loudewijk F. Paulus, “Terorisme”, Buletin Litbang Dephan, vol. v, no. 8 (2002).

51 Adji, "Bali, Terorisme, dan Hak Asasi Manusia".

52 Kamal, "Terrorism, Banditry and Hirabah: Advancing New Shariah Perspectives", p. 12.

53 M. Nurul Irfan and Masyrofah, Fiqh Jinayah (Jakarta: Amzah, 2015), p. 127.

54 Komisi Fatwa MUI, Terorisme (2004), https:/ / mui.or.id/produk/fatwa/754/ terorisme/. 


\section{Rape (al-Ightisāb) as Hiräbah Crimes}

Ibn 'Arabi relates that there was a woman who was kidnapped and raped. When the case was brought to court, some people claimed that the case was not part of the crime of hiräbah, because hiräbah was only related to material (property). Responding to this argument, ibn 'Arabi stated: "Isn't rape worse than robbery?" 55 Explaining his argument, Ibn' Arabi stated: "Humans usually will not fight to protect their property if their lives are threatened, but will fight for things the same if his wife, his daughter will be raped or if honor is betrayed". It is clear that according to ibn 'Arabi, honor is more valuable than wealth and therefore deserves more protection from the law.

Other jurists like Ibn Hazm, Ismail, Mujahid also agreed that rape should be categorized as hiräbah. Ibn Hazm stated that "the mubarib is a person who scares others, also kills, takes property or rapes". ${ }^{56}$ Ismail states that "biräbah is the act of a group of armed men who frighten in an Islamic state by killing people, robbing, raping, or damaging their plants." Even some Shafi'i and Malikiyah jurists also agree that rape is considered biräbah. They argue that disturbing women openly is a crime of hiräbah. ${ }^{57}$ Meanwhile according to the Dzahiriyah, the person who commits hiräbah (mubaribib) is anyone who threatens passers-by and scares road users and kills people, takes property or destroys farji (adultery). However, not all rape is punished by hiräbah. Only sexual relations that are carried out with violence, the use of weapons, and drugs, or any item that can eliminate consciousness can be categorized as hiräbah..$^{58}$

Thus rape, in Islamic criminal law, is closer to the understanding of the crime of hiräbah regulated in the Qur'an 5: 33, not as crime of adultery. Adultery is more likely to occur on agreement; agreement between the perpetrators, without any victims, while rape emphasizes the existence of victims who suffered great losses. In other word, by

55 Abū Bakr Muhammad bin 'Abdullāh al-Ma'rūf bi Ibn 'Arabī, al-Aḥkàm alQur'ān, vol. 2 (Riyadh: Markaz al-Turāth lil-Barmajīyāt, 2013).

56 'Alī b. Aḥmad Ibn Hazm al Andalūsī, al-Muḥalla, vol. 11 (Beirut: Dār al-Kutub al-'Ilmìyah, 2010).

57 Muḥammad ibn Aḥmad Ramlī, Nihāyat al-Mụ̣täj ila Sharḅ al-Minhäj, vol. 8 (Beirut: Dar al-Fikr, 2009).

58 Wajis, The Crime of Hiräbah in Islamic Law, pp. 169-70. 
Kamali, by categorizing notorious rapists as hiräbah, the opportunity to stop them by executing them becomes more realistic. ${ }^{59}$

Rape occurs because of coercion from the perpetrator. The concept of forced action in Islamic law is known as ikrah or force. Etimologically, ikrah described by Alauddin as an act of bringing humans to a case that is definitely not the case he wanted. The word ikrab is found in the Qur'an, 4: 19. According to Ibrahim Halabi, as quoted by Khalida, formulates ikrah in terms of Shari'a, is an act that occurs to someone by someone else where that action escapes of willingness or free will (ikhtiar) from that person. So this indicator of coercion includes the lack of willingness and/or lack of will of someone who is the object of coercion. ${ }^{60}$

In Pakistan, one of the Islamic countries, the issue of rape has been approached from three different perspectives: First, the traditional scholars insist that rape is a form of zina and that it can only be proved by the confession of the culprit or the testimony of four witnesses in accordance with the prescribed standard; Second, Mawlana Islahi developed the wider doctrine of biräbah that includes all forms of fasäd (mischief), including rape, and also asserted that circumstantial evidence can also prove a hadd offence; Third, some of the traditional scholars who uphold the concept of "conflation" (talfiq), or mixing of the opinions of the various schools of law, tried to make a kind of compromise between these diametrically opposed views by suggesting that even if rape was covered by the law of zina it could be proved on the basis of circumstantial evidence. ${ }^{61}$ But The Federal Shariat Court concluded in Rashida Patel that rape is a form of hiräbah, not zina. Influenced by the theory of Islahi, Fida Muhammad Khan J, observed: "Zina bi 'l-jabr is different from the other cases of qina and in our opinion it is a serious kind of fasäd fi " lard (creating mischief and disorder in the land) and biräbah. Hence, for proving this offence the required standard of evidence is that of hiräbah, not qina." ${ }^{62}$

59 Kamal, "Terrorism, Banditry and Hirabah: Advancing New Shariah Perspectives", p. 12.

60 Khalida Zia Istiqomah, "Reformulasi Pengaturan Sanksi Tindak Pidana Perkosaan di Indonesia: Studi Perbandingan Hukum Pidana Positif dan Hukum Pidana Islam”, Kumpulan Jurnal Mahasiswa Fakultas Hukum, vol. 1, no. 1 (2014), pp. 1-19.

61 See Mushtaq Ahmad, "The Crime of Rape and the Hanafi Doctrine of Siyasah", Pakistan Journal of Criminology, vol. 6, no. 1 (2014), pp. 161-92.

${ }^{62}$ Ibid., pp. 167-8. 


\section{Smuggling and Trafficking of Drugs as Hiräbah Crimes}

Smuggling and trafficking of drugs is a crime that is very dangerous for human life. Placement of drugs smuggling and trafficking into biräbah basically follows the nature of khamr which does contain danger. Therefore, consuming khamr has been determined by the nass as a serious crime and is included in the budud category. What are the arguments underlying the construction of drugs smuggling and trafficking as biräbab? Nik Rahim explained that:

When acts of scaring people and robberies committed without killing can be categorized as hiräbah then there is actually no valid reason to prevent the crime of smuggling and drug trafficking as a crime of biräbah. This is simple because the consequences of terrorism and robbery are less dangerous to humans, both physically and psychologically when compared to the consequences of drug smuggling and trafficking. Some people might argue that the crime of smuggling and trafficking in illegal drugs itself does not cause damage or harm to others. Damage only occurs when people misuse the item. Therefore, drug smugglers and traffickers should not be held responsible for this damage because these people have the choice not to buy or abuse the illegal drugs. But if we take a closer look at this argument, it will be seen that drug smugglers and traffickers in fact must be held responsible for causing damage to people indirectly. ${ }^{63}$

Hiräbah has two special elements, namely fighting God and His Messenger and making mischief on earth. So, the smugglers and drugs traffickers allegedly violated the two elements concretely. With regard to the second element, the smugglers and traffickers of the drug have violated two things: first, the law prohibiting illegal drugs can be sold to the public; secondly, by smuggling and trafficking in illegal drugs, this crime has caused damage to the community. Because of the damaging effects of drug smuggling and drug trafficking on society, their actions must be stopped. One way to stop their actions is to impose severe penalties on them by including these actions in the crime of biräbah. ${ }^{64}$

Some countries consider smuggling and trafficking drugs to be very serious crime. Saudi Arabia is presumed to have implemented the law of hiräbah for the smugglers of drugs. Recently, eight foreigners who were

63 Wajis, The Crime of Hiräbah in Islamic Law, pp. 217-8.

64 Wajis, The Crime of Hiräbah in Islamic Law. 
found guilty of drugs smuggling were beheaded. Malaysia is another of the countries that has implemented a mandatory death penalty for the offence of smuggling and trafficking drugs which seems to be in line with the law of hiräbah under the Sharia law. ${ }^{65}$

\section{Hiräbah and the Problems of Criminal Liability}

Another problem with classical Islamic law according to an-Naim is the existence of legal discrimination or the non-application of the principle of equality before the law, such as diyat (fines) for the act of killing a woman according to the classical Muslim's scholars only valued half of the diyat killing men guys. ${ }^{66}$

This kind of problem also found in biräbah crime. The problem based on the question: Who is the muharib? this question arises from the background of debates by jurists about whether the perpetrators of the biräbab include all those involved in the hiräbah crimes, from the beginning of the planning until the realization of the crime, or only those who are the main actors? In other words, is there a need to categorize the hiräbah actors as the main actors and supporting actors or is it sufficient for one category to be the only actors?

In this case there are two opinions; first, those who argue that there is no need to distinguish between the main actors and supporting actors; second, those who consider it necessary to distinguish between the main actors and supporting actors. The first opinion was represented by the Abu Hanifah group, while the second opinion was represented by the Shafi'i group. Abu Hanifah stated that if the robbers conspired, then some of them carried out the action both killing and taking property while some others only helped it, then the legal status for those who helped remained the same as the other robbers. Therefore, it is sufficient that there is an attack both in whole or in part so that had must be imposed on them. The condition is that the group of robberies must be all men. Thus, according to this opinion, people who participated directly involved in taking property, killing, and intimidating, including robbers. Likewise, those who help providing assistance, by way of consultation, instruction

\footnotetext{
${ }^{65}$ Ibid., p. 190.

66 Ibn Rushd, Bidāyat al-Mujtahid wa Nihāyat al-Muqtașid (Cairo: Jumhūrīyat Miṣr al-'Arabiyah, 2017), p. 447; 'Audah, al-Tashrì' al-Jināì al-Islàmì, pp. 155, 214.
} 
and help, also include the perpetrators of hiräbah. This opinion was agreed upon by Imam Malik, Imam Ahmad and Zahiriyah. ${ }^{67}$

Abù Hanifah and his disciple al-Shaybani hold that the perpetrators of hiräbah must be male so that if there is a female member in a biräbah group then the female member of the hiräbab is not subject to punishment. The reason is because assault, deterrence and theft by force and violence usually cannot be done by women because of their tenderness and their physical weakness so it does not fit into the character of violence. ${ }^{68}$ In other word, this is because the necessary show of power and strength is only suited to men. ${ }^{69}$

Meanwhile Shafi'i chose to distinguish the perpetrators in the biräbah crimes, including the main actors and supporting actors. Imam Shafi'i believes that the so-called perpetrators of hiräbah are those who directly conduct hiräbah. Whereas those who did not participate directly, even though he was present at the scene, were not considered as perpetrators of hiräbah, but only as servants who were threatened with ta'zir punishment. ${ }^{70}$

Shafi'i also does not distinguish between male perpetrators and female perpetrators so that all punishments of biräbah are imposed on all biräbah perpetrators. This opinion is in line with Imam Malik, Imam Ahmad, Zahiriyah, Al-Thahawi, and Shi'ites Zaidiyah. According to them, women who participated in hiräbah must still be subject to punishment. There is no distinction between male and female perpetrators as in other budūd crime. ${ }^{71}$

The legal implications of the differences of opinion are certainly very significant. First, in terms of application of the elements of crime. Categorizing the perpetrators of hiräbah differently will have implications

67 Al-Kasāni, Bada'i’ al-Sana'i fi Tartìb al-Sharä’’; Wahba az-Zuhailī, Fiqh al-Islàmì wa-Adillatubū (Beirut: Dār al-Fikr, 1997).

68 Abd. Rahman al-Jaziri, Al-Figh 'alā Mazāhib al-Arba'ah, vol. 5 (Beirut: Dar al-Fikr, 1986); 'Audah, al-Tashrì' al-Jinà't al-Islämì.

69 Al-Kasāni, Bada'i’ al-Sana'i fi Tartīb al-Sharā'i; Kamal, "Terrorism, Banditry and Hirabah: Advancing New Shariah Perspectives".

70 Wahba az-Zuhailī, Fiqh al-Islāmì wa-Adillatubū, vol. 6 (Beirut: Dār al-Fikr, 1997), p. 130; Al-Kasāni, Bada'i' al-Sana'i fi Tartīb al-Sharā'i, 7: 135; 'Audah, al-Tashrì' al-jinà'ì al-Islämì, pp. 641-2.

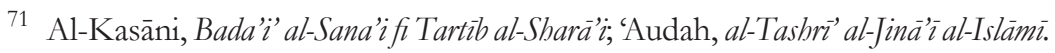


for the application of different elements of crime. The group that embraces the opinion of all perpetrators as the main perpetrators in the biräbah crimes believes that all elements of the hiräbah crimes perfectly exist in every perpetrator, whoever they are and whatever their duties and contributions. And vice versa, the opinion which holds that there is only one main offender, believes that everyone involved in the crime of biräbah represents himself, so that only relates to some elements of the crime. Therefore, they are only responsible for their roles and contributions.

Second, the implications of the criminal liability. This implication is based on the question, does the principle of inclusion in a criminal act (ishtiräke) $)^{72}$ apply in this kind of crime (biräbah)? ishtiräk is together in commiting crime. ${ }^{73}$ The opinion which states that all those involved as the main perpetrators (there is no participant perpetrators), certainly do not apply the principle of inclusion of criminal acts (ishtiräk) in the biräbah crimes. This is because all the people involved are categorized as actors with the same status, namely as the main actors. In contrast to those who hold only one main actor, so the principle of inclusion of a criminal offense (ishtiräk) will be applied in the crime of hiräbah. It is also based on a theory that distinguishes the legal status between one offender and another in a crime in terms of their role and contribution.

Third, the implications on the application of punishment. This condition is a consequenc e of the different perspectives of criminal liability as explained in the second implication. When a crime of hiräbah is treated as an ishtiräk, a variety of sentences will apply, depending on

72 Ishtiräk (deelneming) is the understanding that includes all forms of participation/involvement of people or people both psychologically and physically by carrying out each act so as to form a criminal act. The cooperation can be in the form of: a participant commits a criminal offense with another person; the perpetrators entered into an agreement (agreement) with another person to commit a criminal act; the offender incites others to commit crimes; or the perpetrator provides assistance or an opportunity to commit a crime in various ways, without participating in the act. Islam divides ishtiräk into two, namely ishtiräk mubashir, ie when someone participates directly in committing a crime; and ishtiräk ghairu mubashir, that is when someone participates indirectly in committing a crime. See Abdul Qadir Audah, Ensiklopedi Hukum Pidana Islam, vol. 2 (Jakarta: Kharisma Ilmu, 2008); H. Ahmad Wardi Muslich, Pengantar dan Asas Hukum Pidana Islam (Jakarta: Sinar Grafika, 2004); 'Audah, al-Tashrì al-Jinā' al-Islämī; Hanafi, Asas-Asas Hukum Pidana Islam.

73 'Audah, al-Tashrì' al-Jinā' à-Islämì, p. 357. 
the type of crime and the contribution of the perpetrator in the crime of hiräbah. Likewise, when not treated as an ishtiräk, then the application of the biräbah criminal punishment in the form of one sentence of the same type, namely had hiräbah.

Regarding the different sentences for these male and female perpetrators, Abd al-Azim Syaraf al-Din, as quoted by Paizah, stated: "The view that equates between men and women and the view that distinguishes between both of them in the punishment of biräbah, what is stronger is the view that equates between them. The reason that women are physically weak, so they should not be punished, is actually not a strong reason. Because if so, then the Prophet certainly did not order that women who steal and commit adultery be cut off their hands and also be chastened." 74

The categorization of the perpetrators of biräbah in one type, namely as the main perpetrators appears to provide more legal certainty in the accountability of the biräbah crime. Simply define, this opinion look more appropriate with the equality before the law principle. Considering the size of a person's contribution in a crime is indeed a fundamental aspect of criminal responsibility. However, in the case of biräbah, the existence of the intention to involve oneself in biräbah is the only determining factor that a person deserves to be categorized as the main actor, without considering his real position and contribution. Another important perspective to consider is the existence of repentance institutions. One of the differences between the biräbah verse and the other budud crime verses is the explicit recognition of the repentance institution as an act that has significant legal implications for the perpetrators of hiräbah. Namely if the perpetrators of the hiräbah choose to repent before being caught, then the potential to be threatened with the sentence had to be dropped (forgiven). ${ }^{75}$

In the perspective of human rights, the three elements contained in the crime of hiräbah legislation, i.e. the regulation of criminal acts that are inclusive (yubäribünallāh wa rasülahu wa yas'auna fi al-ard fasädan), the threat of severe and varied penalties, and the existence of institutions

${ }^{74}$ Paizah Haji Ismail, Status Wanita dalam Undang-Undang Jenayah Islam (Kuala Lumpur: Yayasan Dakwah Islamiah Malaysia, 2004), p. 284.

75 Qur'an, 5: 34 
of repentance are guarantees for the enforcement of justice for the community. That is, the three elements express the balancing of biräbah legal construction. Severe punishment provides a guarantee of legal protection for the people's right to their lives and property's security. But on the other hand, Islamic law also gives high appreciation and reward to the perpetrators of hiräbah who choose to cancel their biräbab intentions by repenting.

Discrimination against hiräbah perpetrators, as Hanafi's thought, is not accommodating to the characteristics of modern criminal law. Modern criminal law does not recognize the discriminatory nature between men and women and between Muslim and others. It must equalize all citizens and respect human rights. For this reason, the rules of the modern nation state require that all criminal provisions, before they are enacted, must first pass modern legislation procedures (tried in the legislature) to obtain prior approval. If it is not agreed upon, it must be abandoned. ${ }^{76}$ The question is will Islamic law be accepted by non-Muslims, if they know that in reality the law is discriminatory and will harm them?

\section{E. Hiräbab and the Problems of Corporal Punishment}

As stated before by Sayyid Sābiq, there are four classifications about the punishment of hiräbah crimes; jailed and ta'zir, cross-cut their hands and feet; put to death; and put to death and then crucified for three days so that these conditions are published and the deterrent effect is perfect. All kind of the punishment are based on physical punishment (corporal punishment).

Almost all provisions about human rights except Islamic concept, have extreme response to the punishment of hiräbah. Even not only biräbah, but also in most of the concept of punishment in Islamic criminal law. They assumed that Islamic concept of punishment included in the type of corporal punishment, so tend to be cruel, unhuman, and degrading. Some of them are International Covenant on Civil and Political Right (ICCPR), the Convention Against Torture (CAT), and Other Cruel,

76 Abdullahi Ahmed An-Na'im, Dekonstruksi Syariab; Wacana Kebebasan Sipil, Hak. Asasi Manusia, dan Hubungan Internasional dalam Islam, trans. by Ahmad Suaedy and Amiruddin Arrani (Yogyakarta: LKiS \& Pustaka Pelajar, 1994). 
Inhuman or Degrading Treatment or Punishment. Cruel, degrading or inhuman punishment is outlawed by the ICCPR (art. 7). Articles1 (i) and 16 (i) of the CAT stipulate that no person shall be subjected to torture or to cruel, unhuman or degrading punishment and that states shall take measures to prevent public servants from committing acts of torture or administering such punishment. ${ }^{77}$

What is corporal punishment? The Special Rapporteur on Torture and Cruel, Degrading and Inhuman Treatment or Punishment to the UN Commission on Human Rights formulated this principle as follows:

Corporal punishment is inconsistent with the prohibition of torture and other cruel, inhuman, and degrading treatment or punishment enshrined, inter alia, in the Universal declaration of Human Rights, the International Covenant on Civil and Political Rights, the Declaration on the Protection of All Persons from Being Subjected to Torture and Other Cruel, Inhuman and Degrading Treatment or Punishment and the Convention against Torture and Other Cruel, Inhuman or Degrading Treatment or Punishment. ${ }^{78}$

Meanwhile, according to International human rights organisations such as Amnesty International and Human Rights Watch hold that flogging, the amputation of limbs and retaliation for grievous hurt such as blinding or the pulling out teeth are indeed a form of cruel, inhuman, and degrading punishment. The same is true with regard to certain modes of carrying out the death penalty, such as stoning and crucifixion (at least if the latter punishment is taken to mean that the convict is subjected to it while alive, as is the case in Iran), execution in the same way as the culprit killed his victim (mentioned in Sudanese Penal Code and Some Northern Nigerian Shari'a Penal Codes), or exevution by one of the victim's heirs (which, according to the Iranian Penal Code, the court may allow).$^{79}$ As if to agree with the opinion of critics of Islamic law, An-Na'im state that discrimination, unequal distribution of rights, restrictions on freedom of conscience and belief and denial of popular sovereignty have crept into

77 Peters, Crime and Punishment in Islamic Law: Theory and Practice from the Sixteenth to the Twenty-First Century, p. 175.

78 Ibid., p. 176.

79 Ibid. 
all models where the supremacy of Shari'a is recognized. ${ }^{80}$

It was interesting, that Islamic countries, such as Libya, Saudi Arabia, and Sudan have acceded to the CAT, without any reservation, although their legal systems allow severe punishments such as amputation and execution by stoning. A plausible explanation is that since the CAT does not define the notion of cruel, inhuman or degrading punishment, these states can argue that the syariah penalties, as they are based on God's law, cannot be regarded as cruel, inhuman or degrading. However, the prevailing interpretation of cruel, inhuman or degrading punishment is that it includes all form of corporal punishment. ${ }^{81}$

\section{F. Concluding Remarks}

Hiräbah had been interpreted significantly different between classical Muslim's scholar and modern Muslim's scholars. The spesific characteristic of birabah in the Qur'an and Sunnah shows that the particular elements (arkān al-khās) of its should be definite, clear, and distinct. In contrast with textuality approach by classical Muslim's scholars, modern Muslim's scholars have the same perception to reformulate hiräbah from many perspectives, like definition, principle of liability, and formulation of punishment. This reformulation of hiräbah, and also of Islamic criminal law in general, not only based on compatibility reasons to modernity, but also to harmonize with the changing of time and place. Textual understanding and the principle of individual and locality in biräbah are no longer competent with the principles of modernity which prior to collectivity and universality.

Several stipulations in crime of biräbah by classical scholars show variations in opinions that can affect the criminal liability aspects of crime of hiräbah. For example, about the legal status of the perpetrators of hiräbah which consists of many people who conspire (ishtiräk), or about the legal status of a women the perpetrator of crime of hiräbah. Inaccuracy in responding to these problems can contribute to harm to the application of the principle of equality before the law.

In terms of punishment for biräbah perpetrators, Islamic law faces

80 Tore Lindholm and Kari Vogt (eds.), Islamic Law Reform and Human Rights: Challenges and Rejoinders (Oslo: Nordic Human Rights Publications, 1993), p. 63.

81 Lindholm and Vogt (eds.), Islamic Law Reform and Human Rights, pp. 175-6. 
many challenges from the outsider, including those from human rights activists. Many legal products from human rights institutions tend to be inconsistent with Islam, particularly with regard to the concept of punishment for the perpetrators of biräbah, and for perpetrators of crime in general. Among the triggering factors is disagreement in terms of physical (corporal) punishment and the function of punishment. Physical punishment in Islam is considered still needed because it relates to the deterrent effect and its effectiveness, while the human rights activists consider it a cruel, inhuman and degrading punishment. 


\section{BIBLIOGRAPHY}

"Abdullahi Ahmed An-Na'im, Emory University School of Law", Profile, http:/ /law.emory.edu/faculty/faculty-profiles/annaim-profile.html, accessed 2 Nov 2020.

Adji, Indriyanto Seno, "Bali, Terorisme dan Hak Asasi Manusia”, Kompas, 29 Oct 2002.

Ahmad, Mushtaq, "The Crime of Rape and the Hanafi Doctrine of Siyasah", Pakistan Journal of Criminology, vol. 6, no. 1, 2014, pp. 161-92.

Akaha, Abduh Zulfidar (ed.), Terorisme \& Konspirasi Anti Islam, Jakarta: Pustaka al-Kautsar, 2002.

Al-Barr, Ibn 'Abd, al-Käfi fi Fiqh al-Madīnah al-Mälikì, Beirut: Dar al Kutub al-Ilmiyah, 1999.

Al-Bukhari, Muhammad bin Ismail bin Ibrahim, Sabih al-Bukhari, Beirut: Dar al-Fikr, 1994.

'Ali, Abdullah Yusuf, The Meaning of the Holy Qur'an, Beltsville, MD: Amana Publications, 1995.

Al-Kasāni, 'Alauddin, Bada'i' al-Sana'i fi Tartīb al-Sharäi, vol. 7, Beirut: Dār al-Kutub al-'Ilmiyyah, 1997.

Al-Zuhailī, Wahbah, al-Fiqh al-Shäfíi al-Muyassar, vol. 3, ed. by Muhammad Afifi Abdul Hafiz, Beirut: Dar al-Fikr, 2008.

An-Na'im, Abdullahi Ahmed, Toward an Islamic Reformation: Civil Liberties, Human Rights, and International Law, Syracuse: Syracuse University Press, 1990.

----, Dekonstruksi Syari'ab; Wacana Kebebasan Sipil, Hak Asasi Manusia, dan Hubungan Internasional dalam Islam, trans. by Ahmad Suaedy and Amiruddin Arrani, Yogyakarta: LKiS \& Pustaka Pelajar, 1994.

----, Islam and the Secular State: Negotiating the Future of Shari a, Cambridge: Harvard University Press, 2008.

----, Future of Shari'a, https://scholarblogs.emory.edu/aannaim/ futureof-sharia-2/, accessed 11 Feb 2020.

'Arabī, Abū Bakr Muḥammad bin 'Abdullāh al-Ma'rūf bi Ibn, al-Aḥkām al-Qur'ān, vol. 2, Riyadh: Markaz al-Turāth lil-Barmajīyāt, 2013. 
'Audah, Abd al-Qādir, al-Tashrì' al-Jinàì al-Islāmì, Beirut: Dār al-kutub al-'Tlmiyah, 2009.

Audah, Abdul Qadir, Ensiklopedi Hukum Pidana Islam, vol. 2, Jakarta: Kharisma Ilmu, 2008.

Bassiouni, M. Cherif (ed.), The Islamic Criminal Justice System, London ; New York: Oceana Publications, 1982.

Doi, Abdur Rahman I., Tindak Pidana dalam Syariat Islam, Jakarta: Rineka Cipta, 1992.

El-Fadl, Khaled Abou, Rebellion and Violence in Islamic Law, Cambridge: Cambridge University Press, 2001.

Fadl, Khaled Abou El, Rebellion and Violence in Islamic Law, First edition, Cambridge ; New York: Cambridge University Press, 2001.

Fanani, Muhyar, Membumikan Hukum Langit: Nasionalisasi Hukum Islam dan Islamisasi Hukum Nasional Pasca Reformasi, ed. by Ibnu Burdah, Yogyakarta: Tiara Wacana, 2008.

Hanafi, Ahmad, Asas-Asas Hukum Pidana Islam, Jakarta: Bulan Bintang, 2005.

Ḥiṣnī, Taqī al-Dīn Abū Bakr ibn Muḥammad, Kifāyat al-akhyārfì ḥall Ghāyat al-ikhtișār, vol. 2, Beirut: Dār al-Kutub al-'Ilmīyah, 2012.

'Umayrī, Muḥammad ibn 'Abd Allāh, Musqitāt Hadd al-Hirābah wa Tațíqaàtuhā fì al-Mamlake al-'Arabiyya al-Sa'ūdìyya, Riyadh: Akādīmiyāt Nayif al-'Arabiyya lil al-'Ulūm al-Aminyya, 1999.

Ibn Hazm al Andalūsī, 'Alī b. Aḥmad, al-Muḥalla., vol. 11, Beirut: Dār al-Kutub al-'Ilmīyah, 2010.

Ibn Rushd, Bidāyat al-Mujtahid wa Nihāyat al-Muqtasid, Cairo: Jumhūrīyat Mișr al-'Arabìyah, 2017.

Irfan, M. Nurul and Masyrofah, Fiqh Jinayah, Jakarta: Amzah, 2015.

Istiqomah, Khalida Zia, "Reformulasi Pengaturan Sanksi Tindak Pidana Perkosaan di Indonesia (Studi Perbandingan Hukum Pidana Positif dan Hukum Pidana Islam", Kumpulan Jurnal Mahasiswa Fakultas Hukum, vol. 1, no. 1, 2014, pp. 1-19.

Jackson, Sherman A., "Domestic Terrorism in the Islamic Legal Tradition", The Muslim World, vol. 91, nos. 3-4, 2001, pp. 293-310 
[https://doi.org/10.1111/j.1478-1913.2001.tb03718.x].

al-Jaziri, Abd. Rahman, Al-Fiqh 'alà Maz̄ähib al-Arba'ah, vol. 5, Beirut: Dar al-Fikr, 1986.

Juwana, Hikmahanto, Catatan Singkat RUU Anti Terorisme, Jakarta, 2002.

Kamal, Mohammad Hashim, "Terrorism, Banditry and Hirabah: Advancing New Shariah Perspectives", Islam and Civilisational Renewal., vol. 8, no. 1, 2017, pp. 11-34.

"Khaled Abou El Fadl", Program in Islamic Law, 30 Apr 2019, https:// pil.law.harvard.edu/advisors/khaled-abou-el-fadl/, accessed 11 Feb 2020.

Komisi Fatwa MUI, Terorisme, 2004, https://mui.or.id/produk/ fatwa/754/terorisme/.

Legal Affairs Commission of the Islamic Consultative Assembly, Islamic Penal Code of the Islamic Republic of Iran: Book One \& Book Two, New Haven: Iran Human Rights Documentation Center, 1991.

Lindholm, Tore and Kari Vogt (eds.), Islamic Law Reform and Human Rights: Challenges and Rejoinders, Oslo: Nordic Human Rights Publications, 1993.

Munajat, Makhrus, Dekonstruksi Hukum Pidana Islam, Yogyakarta: Logung Pustaka, 2004.

Muslich, H. Ahmad Wardi, Pengantar dan Asas Hukum Pidana Islam, Jakarta: Sinar Grafika, 2004.

Paizah Haji Ismail, Status Wanita dalam Undang-Undang Jenayah Islam, Kuala Lumpur: Yayasan Dakwah Islamiah Malaysia, 2004.

Paulus, Loudewijk F., “Terorisme”, Buletin Litbang Dephan, vol. v, no. 8, 2002.

Peters, Rudolph, Crime and Punishment in Islamic Law: Theory and Practice from the Sixteenth to the Twenty-First Century, Cambridge: Cambridge University Press, 2005.

"Professor Kamali", International Institute of Advanced Islamic Studies (LAIS) Malaysia, https://iais.org.my/staff-sp-2037227643/professorkamali, accessed 11 Feb 2020.

Ramlī, Muḥammad ibn Aḥmad, Nihāyat al-Muḥtäj ila Sharḥ al-Minhäj, vol. 
8, Beirut: Dar al-Fikr, 2009.

Sābiq, Sayyid, Fiqh Sunnah, vol. 2, Cairo: Dār Fatḥ al-I'lām al-'Arabī, 1999.

Saliba, Issam, "Saudi Arabia: Twin Brothers Charged with Islamic Crime of Hiraba", Global Legal Monitor, 2018, / /www.loc.gov/law/foreignnews/article/saudi-arabia-twin-brothers-charged-with-islamiccrime-of-hiraba/, accessed 12 Feb 2020.

Santoso, Topo, Menggagas Hukum Pidana Islam: Penerapan dalam Syariat Islam dalam Konteks Modernitas, Bandung: Asy-Syaamil Press \& Grafika, 2000.

al-Sharbīnī, Shamsuddīn Muḥammad bin Muhammad al-Khatīb, Mughni al-Mubtāj ilā Ma'rifat Ma'āni al-Alfäăa al-Minhäj, vol. 4, Cairo: Muṣtafā al-Bābī al-Halabi, 1933.

Shața, Sayyid Bakri bin Sayyid Muhammad, I'ānah al-Ṭälibin, vol. 4, Surabaya: Haramain, 2007.

Șiddiqi, Muhammad Iqbal, The Penal Law of Islam, New Delhi: International Islamic Publishers, 1994.

Vogel, Frank E., 'The Trial of Terrorists under Classical Islamic Law', Harvard International Law Journal, vol. 43, 2002, p. 53.

Wajis, Nik Rahim Nik, The Crime of Hiräbah in Islamic Law, Glasgow: Glasgow Caledonian University, 1996.

Zahrah, Muhammad Abū, al-Jarimah wa al-Uqübah fì al-Fiqh al-Islāmì, Cairo: Dār al-Fikr al-'Arabī, 2013.

Zuhailīi, Wahba az-, Fiqh al-Islāmì wa-Adillatuhū, Beirut: Dār al-Fikr, 1997. 
Moh Khasan 